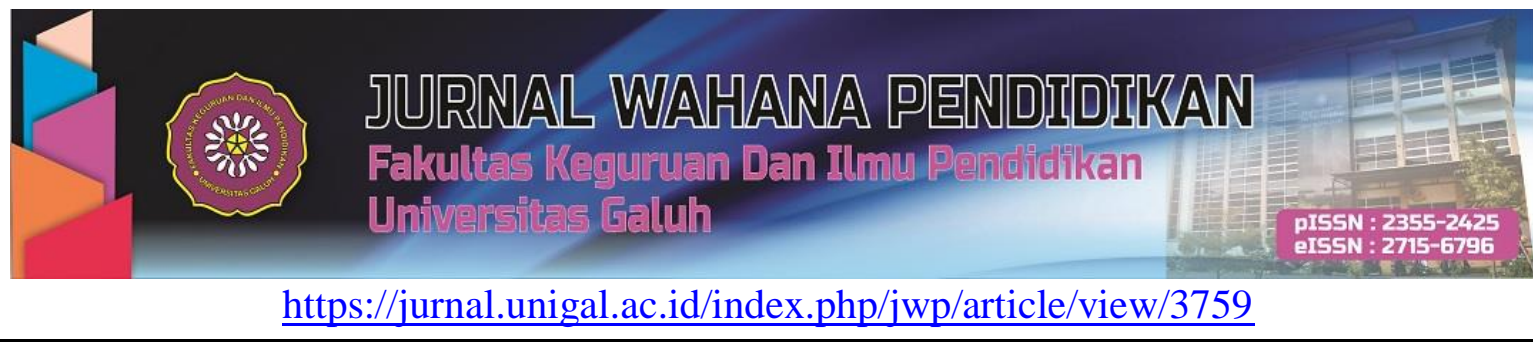

\title{
THE STRATEGY OF MEANING NEGOTIATION IN PRAGMATIC CLASS
}

\author{
Amin Samsul Maarif 1 \\ ${ }^{1}$ MTs Busthomiyah Cilacap, Jawa Tengah \\ Email: aminsyamsul1@gmail.com
}

\begin{abstract}
This article deals with the analysis of how the strategy of meaning negotiation engage in students' interaction in pragmatic class, In conducting this study the writers used qualitative research in which descriptive study as the method of the study. Moreover, observation and interview were the instruments used in collecting the data. Based on the results, It was concluded that the meaning negotiation engage the students' interaction in pragmatic classroom. The students engage emotionally, behaviourally, and cognitively. In addition, the interaction occured between teacher-students and students-students. Furthermore, some problems encountered by the teacher in implementing meaning negotiation strategy in pragmatic class were students' understanding in comprehending the vocabulary, idiom, and meaning. It means that the teacher used to translate the material of English pragmatic material into Indonesian language. Morever, ther writers suggest to further researchers to investigate kinds of students engagement occured in English teaching learning process.
\end{abstract}

Keywords: Second Language Acquisition, meaning negotiation, classroom interaction, students' engagement

\section{ABSTRAK}

Artikel ini membahas tentang bagaimana strategi negosiasi makna terlibat dalam interaksi siswa di kelas pragmatis. Dalam melakukan penelitian ini penulis menggunakan penelitian kualitatif dimana metode penelitiannya adalah studi deskriptif. Selain itu observasi dan wawancara merupakan instrumen yang digunakan untuk mengumpulkan data. Berdasarkan hasil penelitian dapat disimpulkan bahwa makna negosiasi melibatkan interaksi siswa dalam kelas pragmatis. Para siswa terlibat secara emosional, perilaku, dan kognitif. Selain itu juga terjadi interaksi antara guru-murid dan murid-murid. Selain itu, beberapa kendala yang dihadapi guru dalam menerapkan strategi negosiasi makna di kelas pragmatis adalah pemahaman siswa dalam memahami kosakata, idiom, dan makna. Artinya guru biasa menerjemahkan materi materi pragmatis bahasa Inggris ke dalam bahasa Indonesia. Selain itu, penulis menyarankan kepada peneliti selanjutnya untuk menyelidiki macam-macam keterlibatan siswa yang terjadi dalam proses pembelajaran bahasa Inggris.

Kata kunci: Akuisisi Bahasa Kedua, negosiasi makna, interaksi kelas, keterlibatan siswa 


\section{INTRODUCTION}

In recent years there has been an interest in determining whether and how pragmatics can be taught in the classroom. Pragmatics has been defined as 'the study of speaker and hearer meaning created in their joint actions that include both linguistic and non-linguistic signals in the context of socioculturally organised activities'. Following a similar view, Denny (2008) defines pragmatics as meaning in interaction. Meaning is not something which is inherent in the words alone, nor is it produced by the speaker alone, nor by the listener alone. Making meaning is a dynamic process, involving the negotiation of meaning between speaker and hearer, the context of utterance and the meaning potential of the utterance.

Negotiation of meaning occurs in the interactions as a communication strategy to make meaning comprehensible. In a conversation, speakers and interlocutors may employ negotiation of meaning strategy to achieve mutual understanding. Negotiation of meaning is important in language acquisition and second or foreign language learning. With the use of negotiation of meaning, speakers and interlocutors can avoid misunderstanding and communication breakdowns. Rustandi (2013) gives the definition of classroom interaction is the heart of communication and what is communication is all about. Through the definition, classroom interaction is the core of communication in the teaching learning process. The teacher give clear understanding of the material to the students and the student will clearly understand the teachers material through classroom interaction.

In addition, the use of negotiation meaning is more interesting when it occurs in pragmatic class because as one of the speakers is aware of this mismatch, the negotiation strategy can be initiated to solve the problem of non-understanding. Denny (2008) has proposed a largely used model of negotiation, where non-understanding is made up of four parts: a trigger, an indicator, a response and an optional reaction.

To emphasize, the study conducted by Miller (2013) entitled" The negotiation style: a comparative study between the stated and in practice negotiation style" showed that the negotiation style could be occured in interactional classroom. However, the negotiation meaning in pragmatic classroom was not investigated. Another study was conducted by Bartolo (2014) entitled "Pragmatic strategies and negotiation of meaning in ELF talk". They said that this journal discusses about how to what communicative strategies and discourse practices speakers, belonging to different linguistic backgrounds, use to facilitate the achievement of mutual comprehension, is drawn attention to in the present paper. The need to re-examine what it means to learn and teach a global modern language from a different methodological perspective is highlighted. It is therefore suggested that English as a lingua franca, ELF, needs to be investigated as a field of enquiry which requires empirical analysis, not only from a linguistic perspective, but also from a sociolinguistic one.

The last previous study was conducted by Denny (2008) entitled "Teaching the pragmatics of negotiation in New Zealand English". The action research study outlined in this article explored the use of naturalistic semiscripted models to teach the pragmatics of negotiation in a New Zealand tertiary institution. It sought to discover to what extent semi-scripted naturalistic models are useful and which classroom activities are most effective in teaching this feature of spoken language. The findings suggest that, for the majority of the students in this context, naturalistic semi-scripted models are effective learning tools that help the students to reflect on differences and similarities in pragmatic norms between the target language and their first languages. The previous study focus on Communication strategy used and negotiation of meaning text chat and videoconferencing. Meanwhile the present research proposal focus on negotiation meaning practically.

The above three studies did not investigate the implementation of meaning negotiation on the students' classroom interaction in pragmatic class. Furthermore, this study fills the gap by investigating meaning negotiation engage in teacher-student's interaction in pragmatic class. 


\section{Second Language Acquisition (SLA)}

Saville-Troike (2006, p. 2) said that Second Language Acquisition (SLA) refers both to the study of individuals and groups who are learning a language subsequent to learning their first one as young children, and to the process of learning that language. The additional language is called a second language (L2), even though it may actually be the third, fourth, or tenth to be acquired. It is also commonly called a target language $(\mathrm{TL})$, which refers to any language that is the aim or goal of learning. The scope of SLA includes informal L2 learning that takes place in naturalistic contexts, formal L2 learning that takes place in classrooms, and L2 learning that involves a mixture of these settings and circumstances.

Furthermore, according to Rustandi (2013) the study of classroom interaction has received much attention in the field of SLA. A considerable amount of empirical research has been conducted in this area. Several updated research studies have focused on the communication strategies during classroom interaction such as done by Cervantes and Rodriguez (2012). They investigated the communication strategies used by two EFL teachers and their beginner level students. What they did has a close relationship with the present study, because communication strategies is always connected to the concept of meaning negotiation

\section{Meaning Negotiation}

Negotiation of meaning is defined as a series of exchanges conducted by addressors and addressees to help themselves understand and be understood by their interlocutor (Yufrizal, 2007). In other words negotiation of meaning is a process that speakers go through to reach a clear understanding of each other. It is used by learners of second or foreign language to overcome some misunderstandings that might occur in an interaction. When misunderstandings occur in the process of interaction the interlocutor gets difficulties to keep their interaction going on so they try to alter communication strategies including negotiation of meaning as the effective solution. There are four components of negotiation of meaning i.e., trigger, signals, response, and follow-up. Lengluan (2008, p. 2) argues that negotiation of meaning can be promoted in an English classroom, when the teacher constructs an interactive learning environment with appropriate communication tasks. In conversation, a speaker may employ another communication strategy to communicate effectively using negotiation of meaning.

\section{Classroom Interaction}

The communicative process involves interaction between at least two people who share a list of signs and semiotic rules. The concept of interaction is defined as "reciprocal events that require at least two objects and two actions. Interaction occurs when these objects and events naturally influence one another" (Dagarin, 2004). Therefore, interactions do not occur only from one side, there must be mutual influence through giving and receiving messages in order to achieve communication.

The concept of interaction has a significant importance in the classroom too; it is an essential part in learning and teaching processes. In this case, the meaning of interaction is something people can do together i.e. collectively. Obviously, in the classroom it is considered as important for the teacher to manage who should talk, to whom, on what topic, in what language and so on.

\section{METHOD}

A qualitative method was used as a research method in this research. In this case, qualitative research methods were observed and recorded by the writer which comes from various sorts of data, and the methods used to collect them (oral and written language practices, interviews, documents, and observations (Wei \& Moyer, 2008). In this research, the writers used qualitative research because it analyzed detailed data concerning with meaning negotiation that engaged in students' interaction in pragmatic class.

The research participants of this study consist of a lecturer and the 17 students at the second semester. In collecting data, the writer used some instruments. Instrument is implementing 
for apparatus used in performing action (Burns, 2000, p. 650). For this research the writers used classroom observation and interview to investigate the phenomenon in this study.

\section{FINDINGS AND DISCUSSIONS}

There were some points to be discussed in this study. In this point, the result was divided into several points. The first was about how the teacher implemented meaning negotiation in engaging classroom interaction in pragmatic class. The second was about the difficulties and the solution to solve the problem.

The first point to be discussed was the results of this study. the meaning negotiation engage the students' interaction in pragmatic classroom in which the students engage emotionally, behaviourally, and cognitively. In addition, the interaction occured between teacher and the students and students to the other students. Thus, it can be concluded that there was an interaction between students and teacher, and also students and students in pragmatics class. In this case, the results of this study was similar with the study conducted by Denny (2008) entitled "Teaching the pragmatics of negotiation in New Zealand English". The action research study outlined in this article explored the use of naturalistic semi-scripted models to teach the pragmatics of negotiation in a New Zealand tertiary institution. The findings suggest that, for the majority of the students in this context, naturalistic semi-scripted models are effective learning tools that help the students to reflect on differences and similarities in pragmatic norms between the target language and their first languages. The previous study focuses on communication strategy used and negotiation of meaning text chat and video conferencing. Meanwhile the present research focuses on negotiation meaning practically in pragmatic class.

The second was the difficulties and also the solution. The difficulties in applying meaning negotiation strategy in engaging students' interaction in pragmatic was the lack of vocabularies and also the mastering of grammar was still limited. Then, the solution was, the teacher applied L1 or first language to convey the material to make the students more understand. The other solution was give the students example to relate the material with the students' understanding. This findings was relevant with the previous study that conducted by Bartolo (2014) entitled "Pragmatic strategies and negotiation of meaning in ELF talk". They said that this journal discusses about how to what communicative strategies and discourse practices speakers, belonging to different linguistic backgrounds, use to facilitate the achievement of mutual comprehension. This findings was similar in analysing the problem and the solution to learn pragmatics by using meaning negotiation strategies.

\section{CONCLUSIONS}

The meaning negotiation engage the students' interaction in pragmatic classroom in which the students engage emotionally, behaviourally, and cognitively. In addition, there was interaction occured between teacher and the students and students to the other students. The problem encountered by the lecturer in implementing meaning negotiation strategy in pragmatic class was two main difficulties. First, students' understanding in comprehending the vocabularies, idiom, and meaning because the pragmatic need extra understanding about those parts. Therefore, sometimes the teacher also used the L1 or first language to teach the students about pragmatic material about the use of utterance, idiom, and vocabulary because the students lack of understanding in comprhending the material. The second difficulties in interaction in pragmatic classroom was grammar. In conclusion, the solutions for solving the problem was familiarizing the students with the vocabulary and grammar.

\section{REFERENCESS}

Bartolo, A. (2014). Pragmatic strategies and negotiation of meaning in ELF talk. EL.LE, 3, 3, 2014, pp. 453-464. 
Burns, R. (2000). Introduction to research methods. Melbourne: Pearson Education Australia Pty Limited.

Carventes \& Rodriguez. (2012). The use of communication strategiesin the beginner of EFL classroom. Gist Eduaction and Learning Reasearch Journal. (6) 11-128

Denny, K. (2008). Teaching the pragmatics of negotiation in New Zealand English. The European Journal of Applied Linguistics and TEFL, 1(1), 35-49.

Dagarin, M. (2004). Classroom interaction and comunication strategies in learning English as a foreign language. English Language Overseas Perspectives and Enquiries (ELOPE) Journal, 1 (1-2), $127-139$.

Lengluan, N. (2008). An analysis of conversational exchanges between grade 12 Thai sudents and native English speakers via a chat program: Strategies of negotiation for meanings. Bangkok: Graduate School, Srinakharinwirot University.

Miller, D. (2013). The negotiation style: a comparative study between the stated and in practice negotiation style. Procedia - Social and Behavioral Sciences 124 ( 2014 ) 200 - 209

Rustandi, A. (2013). Meaning negotiation between teachers and students in a fledgling international standardized school. International Journal of English and Education. Vol. 2, Issue 3, July 2013.

Saville-Troike (2006). Introduction to Second Language Acquisition. University of Arizona : Cambridge University Press.

Wei, J. C., \& Moyer, A. G. (2008). Qualitative Data Analysis and Interpretation in Counseling Psychology: Strategies for Best Practices. The Counseling Psychologist, 35(3), 369-403.

Yufrizal , H. (2007). An Interaction to Second Language Acqquisition ( a text book for ESL learners and English teacher. Language Learning, 40, (1): 539-556. 
Jurnal Wahana Pendidikan, 7(2), 223-228, Agustus 2020 P-ISSN: 2355-2425 dan E-ISSN : 2715-6796 